\title{
Production and identification of two antifungal terpenoids from the Posidonia oceanica epiphytic Ascomycota Mariannaea humicola IG100
}

\author{
Lorenzo Botta ${ }^{1}$, Raffaele Saladino ${ }^{1}$, Paolo Barghini ${ }^{1}$, Massimiliano Fenice ${ }^{1,2}$ and Marcella Pasqualetti ${ }^{1,3^{*}}$ (i)
}

\begin{abstract}
Background: Marine fungi are an important repository of bioactive molecules with great potential in different technological fields, the annual number of new compounds isolated from marine fungi is impressive and the general trend indicates that it is still on the rise. In this context, the antifungal and antimicrobial activity of the marine strain Mariannaea humicola IG100 was evaluated and two active terpenoids were isolated and characterized.

Methods: Preliminary screening of activity of marine strain IG100 was carried out by agar plug diffusion methods against fungal (Penicillium griseofulvum TSF04) and bacterial (Bacillus pumilus KB66 and Escherichia coli JM109) strains. Subsequently, inhibition tests were done by using the cultural broth and the organic extract (ethyl acetate, EtOAc) by the agar well diffusion methods. The main active fractions were identified and tested for their antifungal activity against P. griseofulvum TSF04 in a 24 wells microplate at different concentrations (1000, 100, 10 and $1.0 \mu \mathrm{g} / \mathrm{mL}$ ). Two active compounds were characterized and their relative MIC measured by the broth micro-dilution methods in a 96-well microplate against Aspergillus flavus IG133, P. griseofulvum TSF04, and Trichoderma pleuroticola IG137.
\end{abstract}

Results: Marine strain IG100 presented significant antifungal activity associated with two active compounds, the terpenoids terperstacin $\mathbf{1}$ and 19-acetyl-4-hydroxydictyodiol 2. Their MIC values were measured for A. flavus (MIC of $7.9 \mu \mathrm{g} / \mathrm{mL}$ and $31.3 \mu \mathrm{g} / \mathrm{mL}$ for $\mathbf{1}$ and $\mathbf{2}$, respectively), P. griseofulvum (MIC of $25 \mu \mathrm{g} / \mathrm{mL}$ and $100 \mu \mathrm{g} / \mathrm{mL}$ for $\mathbf{1}$ and $\mathbf{2}$, respectively) and T. pleuroticola (MIC $>500 \mu \mathrm{g} / \mathrm{mL}$ and $125 \mu \mathrm{g} / \mathrm{mL}$ for $\mathbf{1}$ and $\mathbf{2}$, respectively). They showed a rather good fungistatic effect.

Conclusions: In this study, the first marine strain of M. humicola (IG100) was investigated for the production of bioactive molecules. Strain IG100 produced significant amounts of two bioactive terpenoids, terperstacin $\mathbf{1}$ and 19-acetyl4-hydroxydictyodiol 2. The two compounds showed significant antifungal activities against A. flavus IG133, T. pleuroticola IG137 and P. griseofulvum TSF04. Compound $\mathbf{2}$ was identified for the first time in fungi.

Keywords: Mariannaea humicola, marine fungi, antifungal activity, terpestacin, fungal xenicanes

*Correspondence: mpasqual@unitus.it

${ }^{3}$ Laboratory of Ecology of Marine Fungi (Conisma), University of Tuscia, Largo Università snc, 01100 Viterbo, Italy

Full list of author information is available at the end of the article

\section{Introduction}

Marine environments are sources of biological and chemical diversity, as well as a limitless resource of unexploited and unknown microorganisms. In addition, oceans are enormous repository of natural substances with applications in food and detergent industries, medical chemistry, 
biotechnology and biosensing [1-3]. To date, several drugs are derived from marine environments [4], and about 30.000 new bioactive molecules have been identified to asses a $\$ 5$ billion global market $[5,6]$.

Nevertheless, the exploitation of bioactive molecules from marine origin is still scarce if compared to other natural environments $[1,7]$, especially in the case of marine fungi $[8,9]$. In the last decades, the interest in marine and marine derived fungi has been growing due to their high efficacy in the synthesis of secondary metabolites $[4,5,10-18]$. These organisms are also promising sources of enzymes useful in different technological applications [19-21]. In this context, fungi isolated in highly stressing environments (i.e. from contaminated sites or hypersaline environments) have been studied and applied in the fine and specialty chemical fields, as well as in the production of biodiesel and bioremediation [9, 22$26]$. The annual number of new compounds isolated from marine fungi is impressive and the general trend indicates that it is still on the rise [23]. The posidonia meadows represent the most important coastal ecosystem in subtidal shallow waters of the Mediterranean Sea [27, 28]. The seagrass Posidonia oceanica hosts a great variety of fungi associated to leaves, rhizomes, roots and matte. In particular, fungi related to the leaf district are characterized by a high content of tannic acids and represent an interesting source of new bioactive molecules [29]. A great heterogeneity of fungal colonisers from different posidonia meadows in Tyrrhenian Sea was reported [30-32], and their use in biotechnological applications is still increasing [20, 29]. Mariannaea humicola, belonging to Ascomycetes (Hypocreales, Nectriaceae), is generally recognised as a soil saprophytic fungus (ethimology: name refers to the soil substrate from which this fungus was isolated), [33]. Recently, the first marine strain of the species (M. humicola IG100) was isolated within an ecological study on the marine microbial biodiversity in a $P$. oceanica meadow [30]. Here we report the purification and isolation of two secondary metabolites of the terpenoid family from $M$. humicola IG100, characterized by a significant antifungal activity against Penicillium griseofulvum and Aspergillus flavus. The antimicrobial activity of these compounds was also evaluated against Gram negative and positive bacteria.

\section{Results and discussion}

\section{Phylogenetic analysis of the fungus}

The strain IG100 is well adapted to the sea conditions and its growth preferences permitted to considered this fungus as a marine strain of M. humicola. Actually, the strain is a facultative halophile (range of salinity tolerance $0-152 \% \mathrm{NaCl}-$ optimum at $20 \%$ ) with a sub-mesophilic behaviour, being able to grow in the range of $10-35{ }^{\circ} \mathrm{C}$, with optimum at $25^{\circ} \mathrm{C}$ [30]. The taxonomical identification was based on the ITS (GenBank accession number: MG976446) and $\beta$-tubulin gene (GenBank accession number: MH001469) markers [30]. In this study a phylogenetic analysis based on the $\beta$-tubulin gene was carried out within the Mariannaea genus using the GenBank database, which already include the IG100 strain (Fig. 1). All sequences relative to the Mariannaea species present in NCBI were considered. The phylogram clearly grouped IG 100 with two different strains of M. humicola with a sequence similarity of $98 \%$. The phylogenetic analysis confirmed the previous taxonomical identification [30]. In addition, a certain degree of $\beta$-tubulin gene differentiation in the marine strain IG100 was observed with respect to other species of M. humicola, namely CBS 102,628 (KM232013, from decayed wood), and CBS 740.95 (KM232012, from soil). These data are in agreement with results of others that compared marine strains and their terrestrial counterparts $[34,35]$.

\section{Biological activity of strain IG100}

The preliminary plug screening [36] of strain IG100 was carried out using 12 days old agar plate cultures (MEAs) against $P$. griseofulvum, that is a common toxigenic postharvest fungal pathogen [37]. In addition, Gram positive and Gram negative bacteria (Bacillus pumilus and Escherichia coli, respectively) were tested (Table 1). The plugs of M. humicola IG100 revealed the presence of antifungal activity characterized by an inhibition area of $85 \pm 5$ $\mathrm{mm}^{2}$ at $48 \mathrm{~h}$ (Fig. 2a), and of $43 \pm 3 \mathrm{~mm}^{2}$ at $72 \mathrm{~h}$ (Fig. 2b). The asymmetrical shape of the inhibition zone was due to the release of secondary metabolites at the fungal growing front. No activity was observed against both types of bacteria. On the basis of the activity observed in the preliminary test, the subsequent experiments have been carried out in liquid cultures (Malt saline medium) and the relative inhibition tests were done by using both the cultural broth alone and the crude organic extract (ethyl acetate, EtOAc) of the whole culture (12 days of cultivation). The broth activity was evaluated after 7,14 and 21 days of growth by the well diffusion method [36] (Table 1), but no inhibition against the test organisms was recorded. By contrast, the organic extract $(0.6 \mathrm{mg} /$ $\mathrm{mL}$, tested in the presence of $2 \%$ DMSO) after 12 days of cultivation showed a clear antibacterial and antifungal activity against $B$. pumilus and P. griseofulvum. No activity was observed against $E$. coli. In particular, the antifungal activity of the organic extract was $70-72 \%$ of the positive control at $48 \mathrm{~h}(0.05 \mathrm{mg} / \mathrm{mL}$ Myconazole). The antibacterial activity against $B$. pumilus was significantly lower than the antifungal one, with an inhibition area of $28-31 \%$ of the positive control $(0.2 \mathrm{mg} / \mathrm{mL}$ Streptomycin) after $24 \mathrm{~h}$ of incubation (Table 1 ). 


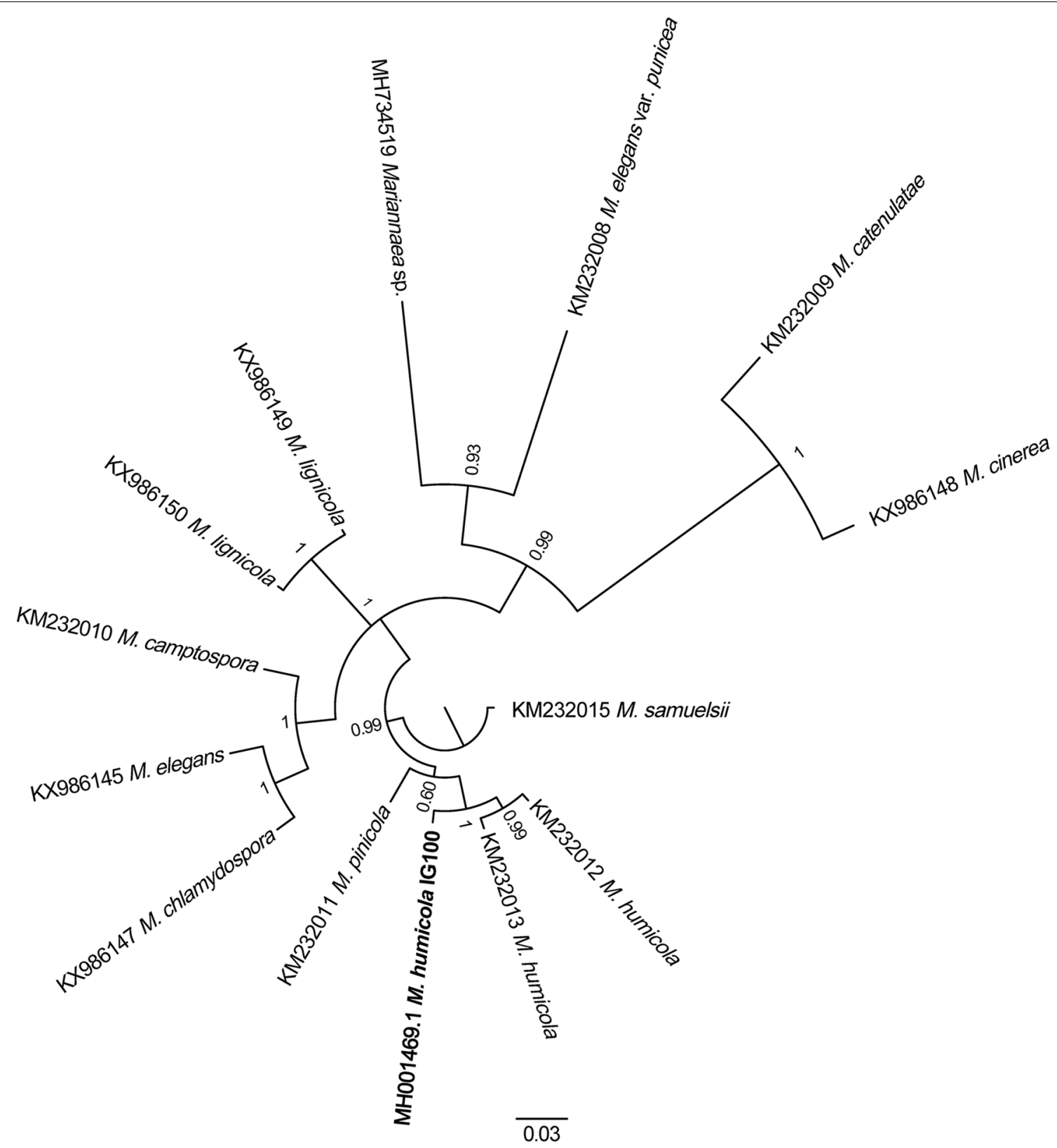

Fig. 1 Bayesian phylogram based on the $\beta$-tubulin gene partial sequences for genus Mariannaea. Branch number indicates Bayesian Posterior Probability analysis (BPP)

\section{Identification of bioactive compounds and screening} of antifungal activity

Repeated cycles of flash-chromatography allowed to yield five major fractions (PO1-PO5) from the organic extract. The antifungal activity of PO1-PO5 against P. griseofulvum was preliminary tested in a 24 microwell plate at different concentrations (1000, 100, 10 and $1.0 \mu \mathrm{g} / \mathrm{mL}$ ). A complete inhibition of the mycelial growth was observed for PO3 and PO5 at 100 and $1000 \mu \mathrm{g} / \mathrm{mL}$, respectively, with a significant interference on the fungal growth until concentration of $1.0 \mu \mathrm{g} / \mathrm{mL}$ (Fig. 3). The other fractions showed only slight (PO1 and PO2) or no antifungal activity (as documented in Fig. 3 for PO4). Fractions PO3 and PO5 were further purified by semipreparative high performance liquid chromatography (HPLC) and the corresponding compounds were isolated and characterized. 

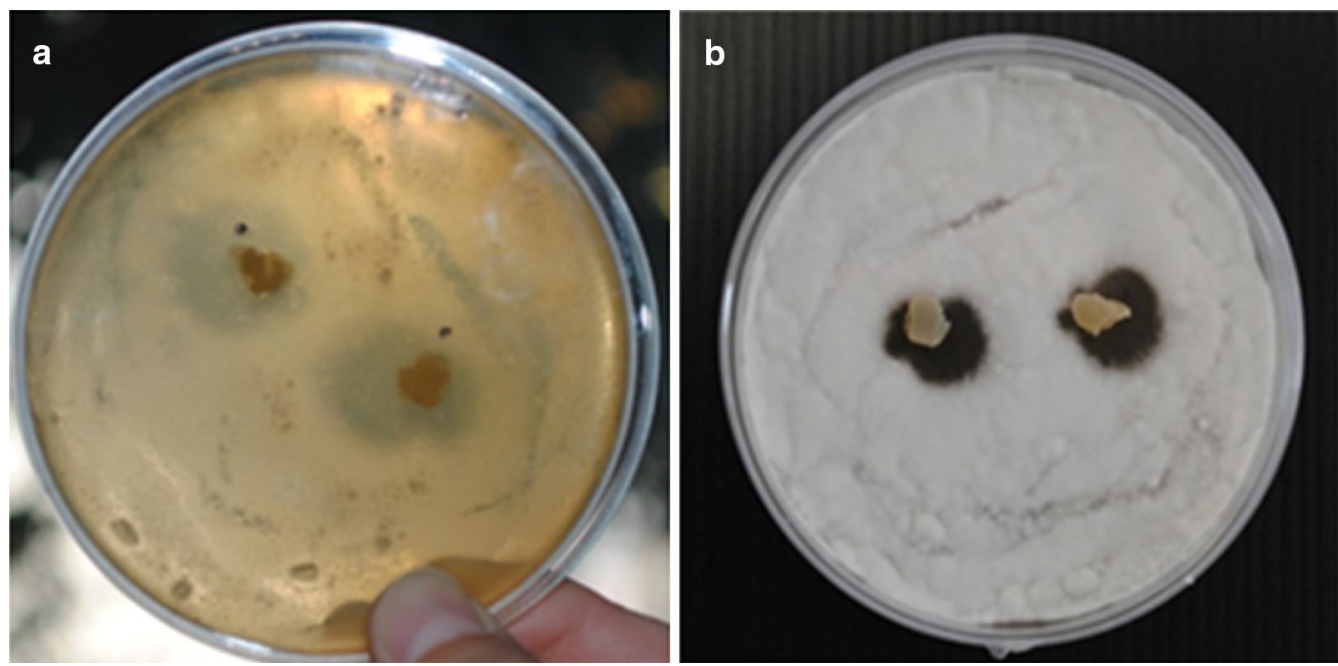

Fig. 2 Preliminary agar plug screening (diffusion method) of M. humicola against P. griseofulvum. Panel a: activity at 48 h. Panel b: activity at $72 \mathrm{~h}$

Table 1 Summary of preliminary screening test

\begin{tabular}{|c|c|c|c|}
\hline & \multirow[t]{2}{*}{ Agar plug diffusion method } & \multicolumn{2}{|c|}{$\begin{array}{l}\text { Agar well diffusion } \\
\text { method }\end{array}$} \\
\hline & & Broth* & Extract \\
\hline \multirow[t]{2}{*}{$\begin{array}{l}\text { incubation } \\
\text { time (h) }\end{array}$} & Linear inhibition (mm) & \multicolumn{2}{|c|}{$\begin{array}{l}\text { Inhibition to the control } \\
(\%)\end{array}$} \\
\hline & P. griseofulvum & & \\
\hline 48 & $6.3 \pm 0.3$ & No effect & $70-72$ \\
\hline \multirow[t]{2}{*}{72} & $4.5 \pm 0.2$ & No effect & $53-55$ \\
\hline & B. pumilus & & \\
\hline 24 & No effect & No effect & $28-31$ \\
\hline \multirow[t]{2}{*}{48} & No effect & No effect & $18-22$ \\
\hline & E. coli & & \\
\hline 24 & No effect & No effect & No effect \\
\hline 48 & No effect & No effect & No effect \\
\hline
\end{tabular}

* Cultural broth at 21 days was reported as selected sample

\section{Structural characterization of active compounds}

The isolated compounds were identified as terpestacin 1 (from PO3) and 19-acetyl-4-hydroxydictyodiol 2 (from PO5) (Fig. 4). Terpestacin 1, obtained as a paleyellow oil, was unambiguously identified by comparison with data previously reported [38]. The HRESIMS analysis yielded the expected chemical formula for $\mathbf{1}$ $\left(\mathrm{C}_{25} \mathrm{H}_{38} \mathrm{O}_{4}\right)$, and the ${ }^{13} \mathrm{C}$ NMR analysis showed all the expected carbon signals, corresponding to one carbonyl moiety $(\delta 208.0 \mathrm{ppm})$, six olefinic carbons $(\delta 138.3$, 136.7, 133.1, 129.1, 124.5, $121.7 \mathrm{ppm})$, five methyl groups $(\delta 16.4,15.8,15.5,14.610 .7 \mathrm{ppm})$ and one oxymethylene moiety ( $\delta 66.3 \mathrm{ppm})$. In accordance with the proposed structure (Fig. 4), the ${ }^{1} \mathrm{H}$ NMR analysis

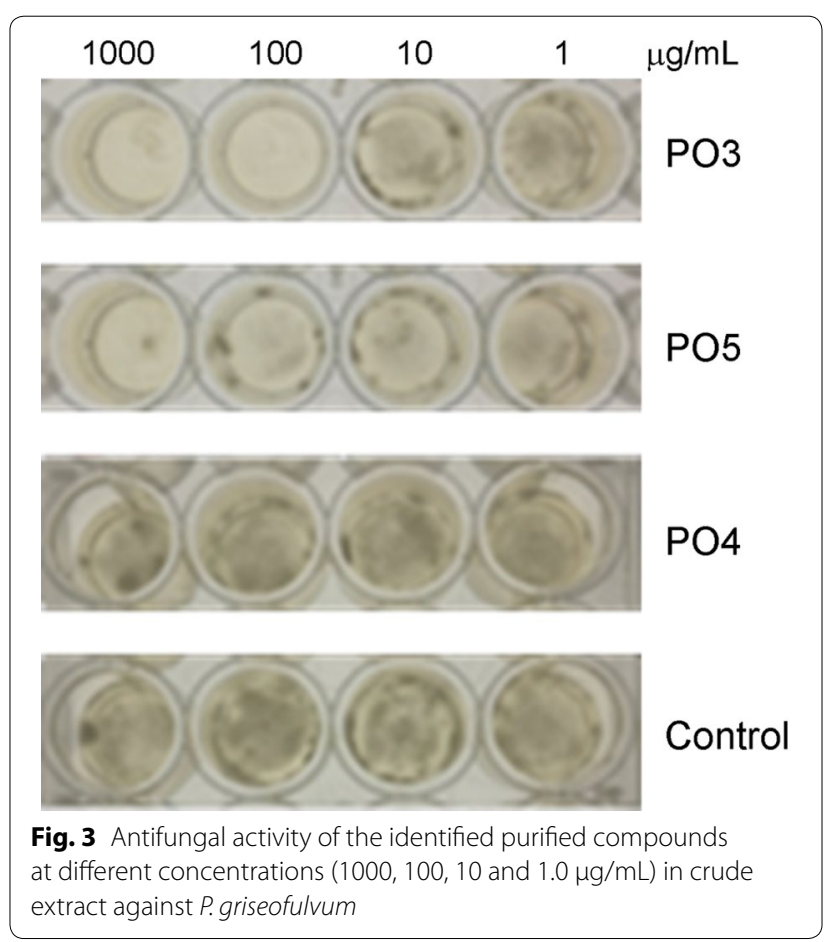

showed the typical signals for the $\mathrm{sp}^{2}$ hydrogens on carbons $\mathrm{C}-3, \mathrm{C}-7$, and $\mathrm{C}-13$ at $\delta 5.41,5.25,5.14 \mathrm{ppm}$, respectively. In addition, the presence of a signal at $\delta$ $4.07 \mathrm{ppm}$, corresponding to the proton located on C-11, definitively confirmed the structure of 1 with respect to the possible epimer 11-epiterpestacin (not shown). ${ }^{1} \mathrm{H}$ NMR signals of five methyl groups $(\delta 1.65,1.64,1.58$, 1.30 , and $1.01 \mathrm{ppm}$, respectively), and of two methines ( $\delta 2.72$ and $2.68 \mathrm{ppm}$ ), completed the assignment. 


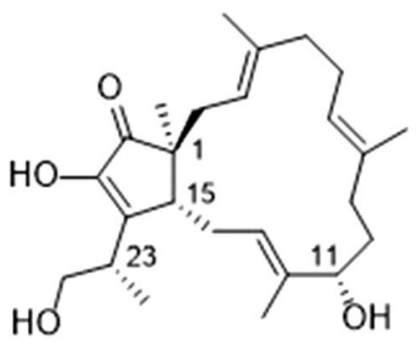

terpestacin 1

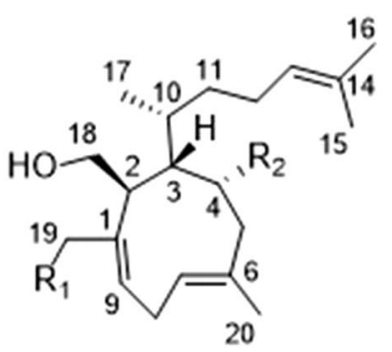

$\mathrm{R}_{1}=\mathrm{OAc} ; \mathrm{R}_{2}=\mathrm{OH}:$ 19-acetyl-4-hydroxydictyodiol 2

$\mathrm{R}_{1}=\mathrm{OH} ; \mathrm{R}_{2}=\mathrm{H}$ : dictyodiol 3

Fig. 4 Chemical structure of terpestacin 1, 19-acetyl-4-hydroxydictyodiol $\mathbf{2}$ and dictyodiol $\mathbf{3}$

Terpestacin 1 was first isolated from the soil fungus Arthrinium sp. [39], and subsequently it was detected in several other fungi derived from saprotrophs, endobiotic symbionts (endophytes, gut of animals) and phytoparasites [40-43]. Among them, only two marine derived fungi were reported to produce 1, Fusarium proliferatum a mangrove-derived endophytic fungus, and Arthrinium sp. isolated from the gut of a marine crab [41, 42]. Terpestacin-producing fungal species belong to the subphylum Pezizomycotina (Ascomycota) and are distributed into several classes (Sordariomycetes, Dothideomycetes, Leotiomycetes, Eurotiomycetes), orders (Hypocreales, Pleosporales, Thelebolales, Onygenales, Botryosphaeriales, Helotiales) and families (Nectriaceae, Apiosporaceae, Pleosporaceae, Thelebolaceae, Onygenaceae, Botryosphaeriaceae, Rutstroemiaceae). In addition, the biosynthetic gene cluster for terpestacin $(t p c)$, identified from Bipolaris maydis, and from other homologous gene clusters, have been found in phytopathogenic strains [40]. Compound $\mathbf{1}$ is characterized by several biologic activities, including antiviral [39], anticancer [44, 45], antiangiogenic and cytotoxic effects (against several test cell lines and brine shrimps) [45, 46], and it was reported as a phytotoxic metabolite produced by pathogenic fungi in plants (Neofusicoccus batangiarum on Opuntia ficusindica; Rustroemia capillus-albis on Bromus tectorum; Bipolaris sorokoniana on wheat and barley) [43, 47, 48]. The studies regarding the antifungal or mycotoxic activity of terpestacin are limited to only three phytopathogen fungal species (A. brassicicola, B. cinerea and F. graminearum). In these latter cases a hyphal growth reduction of the test organisms was observed as a possible consequence of an allelopathic action [49].

The 19-acetyl-4-hydroxydictyodiol 2 (xenicane-type diterpene) was obtained as a colourless oil and its structure was confirmed by comparison with data previously reported [50]. The molecular formula of $\mathrm{C}_{22} \mathrm{H}_{36} \mathrm{O}_{4}$ obtained by HRESIMS analysis was in accordance with the propose structure. IR and ${ }^{13} \mathrm{C}$ NMR analyses showed the presence of a carbonyl function $\left(1737 \mathrm{~cm}^{-1}\right.$ and $\delta$ 142.4 ppm, respectively). The presence of this carbonyl group is important to distinguish compound $\mathbf{2}$ from another similar xenicane-type diterpene, dictyodiol $\mathbf{3}$ (Fig. 4). In addition, ${ }^{13} \mathrm{C}$ NMR spectrum highlighted the presence of all expected olefinic carbons $(\delta$ 135.2, $131.9,130.0,128.5$, and $124.5 \mathrm{ppm}$, respectively), two oxy-methylenes ( $\delta 67.0$ and $60.8 \mathrm{ppm})$, one oxy-methine ( $\delta 74.6 \mathrm{ppm})$, and one methyl carbon $(\delta 20.4 \mathrm{ppm})$. The ${ }^{1} \mathrm{H}$ NMR confirmed the presence of the protons on the olefinic sp ${ }^{2}$ carbons C-7, C-9, and C-13 ( $\delta$ 5.30, 5.82 and $5.07 \mathrm{ppm}$, respectively), and of the methyl groups in positions $\mathrm{C}-15, \mathrm{C}-16, \mathrm{C}-17$ and $\mathrm{C}-20(\delta 1.60,1.68,1.02$, and 1.97 ppm), respectively.

Xenicanes are a large class of marine diterpenoids featuring a cyclononane ring as a common structural denominator [51]. These compounds have been detected in several species of brown algae belonging to the genera Dictyota and Dilophus [51,52] and could be involved in defensive processes, which greatly contributes to the successful survival and reproduction of the host in diverse marine environments. The xenicanes are characterized by antiproliferative, anti-inflammatory, and antifungal effects. Information on their in vivo activity is still lacking [53]. As far as we know, compound 2 was isolated previously only from Dictyota plectens [50] and it was never detected in fungi. Thus, the presence of $\mathbf{2}$ in brown algal extracts, which may be due to the release of the compound from algicolous fungi, cannot be completely ruled out.

\section{Minimal inhibitory concentration of the purified compounds}

Considering the quite good antifungal activity observed in the preliminary analyses, a further biological assay was 
carried out in order to determine the minimal inhibitory concentration (MIC) of compounds 1 and $\mathbf{2}$ against $P$. griseofulvum, A. flavus and T. pleuroticola. The halotolerant fungi $A$. flavus and T. pleuroticola were considered for their ecological, agronomical, economical and clinical significance. A. flavus is the main agent of human allergic and bronchial aspergillosis of pulmonary infections in immunocompromised patients [54]. In addition, this species produces very harmful mycotoxins (aflatoxins, polyketide secondary metabolites that are potentially carcinogenic) in oil-rich seeds (corn, cotton, peanuts, hazelnuts and walnuts) [55]. T. pleuroticola is a mycoparasite causing severe green mould diseases in the commercial fungal genus Pleurotus [56].

The MIC values of compounds $\mathbf{1}$ and $\mathbf{2}$ were evaluated in a 96 microwell plate against the selected test fungi (Table 2). The organic extract (Mix) and
Myconazole were used as references (Table 2). The isolated compounds showed higher antifungal activity than the whole organic extract, with the only exception for $\mathbf{2}$ in the case of $P$. griseofulvum. The most sensitive species was A. flavus (Fig. 5) with a MIC value of $7.9 \mu \mathrm{g} / \mathrm{mL}$ and $31.3 \mu \mathrm{g} / \mathrm{mL}$ for 1 and 2 , compound 1 being the most active derivative. A similar behaviour was observed for $P$. griseofulvum. By contrast, $T$. pleuroticola showed to be definitely more sensitive to 2 (MIC $125 \mu \mathrm{g} / \mathrm{mL}$ ) than to $\mathbf{1}(>500 \mu \mathrm{g} / \mathrm{mL})$. In addition, a significant growth reduction was observed at concentrations much lower than MIC (Table 2). In all cases the activity was fungistatic, while no fungicidal action was recorded as demonstrated by subsequent culturing of the treated fungi. Moreover, microscopic observations showed that conidial germinations of the tested fungi were not completely inhibited by the extract, which acted mainly blocking the hyphal growth.

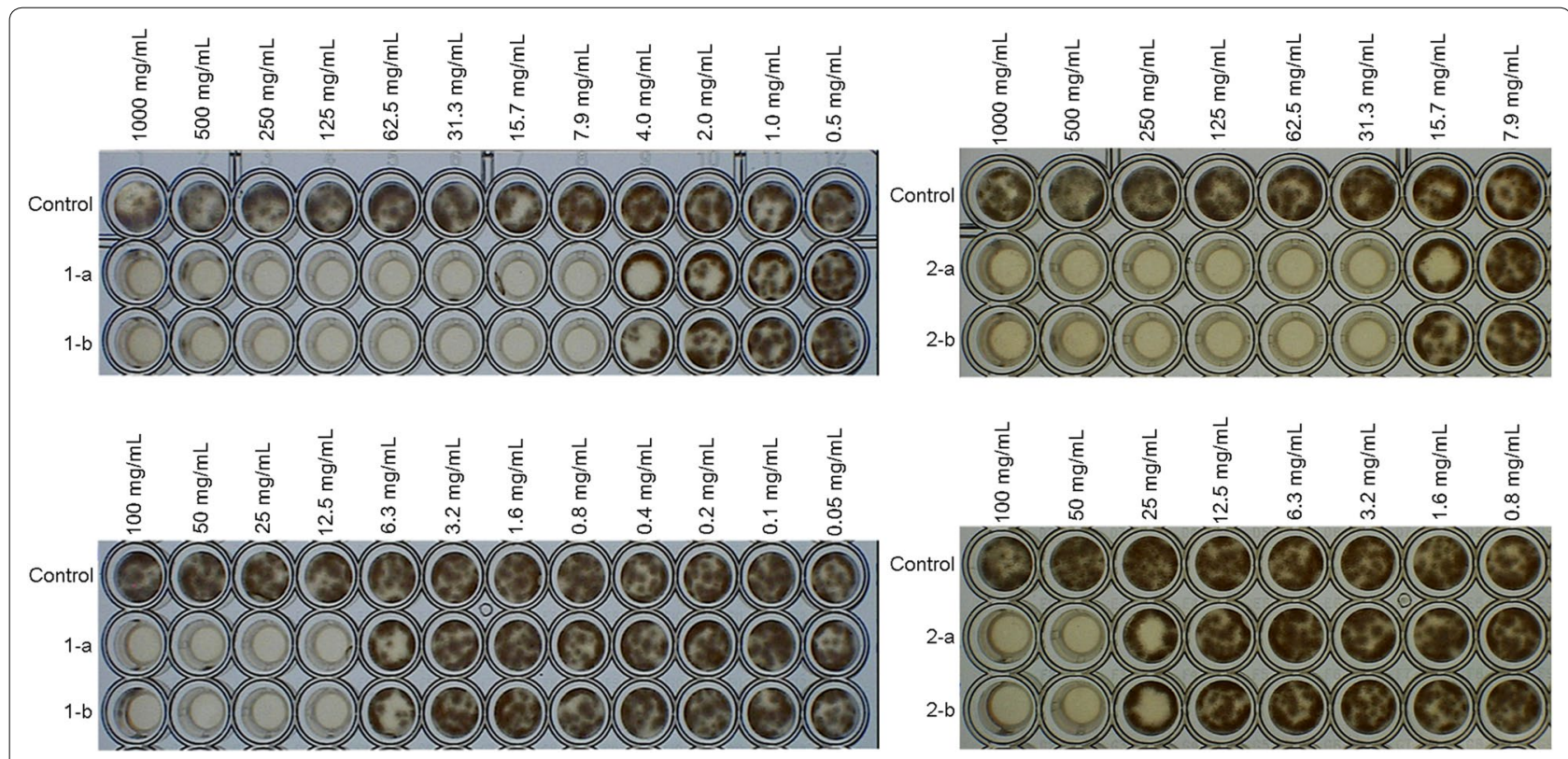

Fig. 5 MIC evaluation (Micro dilution assay) of the purified active components $\mathbf{1}$ and $\mathbf{2}$ in A. flavus

Table 2 Minimal inhibitory concentration (MIC) and growth reduction (GR) values of the organic extract (Mix) and of compounds 1 and 2

\begin{tabular}{|c|c|c|c|c|c|c|}
\hline & \multicolumn{2}{|c|}{ P. griseofulvum } & \multicolumn{2}{|c|}{ A. flavus } & \multicolumn{2}{|c|}{ T. pleuroticola } \\
\hline & MIC & GR & MIC & GR & MIC & GR \\
\hline Mix & 100 & 25 & 62.5 & 31.3 & $>500$ & 125 \\
\hline 1 & 25 & 7.9 & 7.9 & 4.0 & 500 & 250 \\
\hline 2 & 100 & 25 & 31.3 & 15.7 & 125 & 50 \\
\hline Control & 2 & - & 0.5 & - & 1 & - \\
\hline
\end{tabular}




\section{Conclusions}

The marine strain IG100, cultivated in appropriate conditions (saline medium, $\mathrm{NaCl} 3.5 \%$ ), produced significant amounts of two bioactive terpenoids, terperstacin 1 and 19-acetyl-4-hydroxydictyodiol $2(9.1 \mathrm{mg}$ and $8.9 \mathrm{mg}$, respectively from $55 \mathrm{mg}$ of EtOAc extract). The two compounds showed significant antifungal activities. Compound 1 was characterized by higher activity on $A$. flavus (MIC $7.9 \mu \mathrm{g} / \mathrm{mL}$ ) and P. griseofulvum (MIC $25 \mu \mathrm{g} /$ $\mathrm{mL}$ ) compared to compound 2 (MIC 31.3 and $100 \mu \mathrm{g} /$ $\mathrm{mL}$, respectively). On the other hand, the latter showed higher antifungal activity against T. pleuroticola (MIC $125 \mu \mathrm{g} / \mathrm{mL}$ ) than 1 (MIC $500 \mu \mathrm{g} / \mathrm{mL}$ ). Both compounds showed a significant antifungal activity against three toxinogenic/pathogenic fungal species representing genera with large number of species and great significance in ecological, agronomical, economical and clinical fields. It is worth noting that compounds $\mathbf{1}$ and $\mathbf{2}$, produced by the epiphytic fungus $M$. humicola, could exert for the host (i.e. Posidonia oceanica) a specific defensive role, in accordance with the general behaviour reported for xenicanes produced by brown algae [52].

\section{Materials and methods}

\section{Microorganisms}

The strain IG100 was isolated from the marine phanerogam Posidonia oceanica in the Tyrrhenian Sea and cryogenically maintained at $-40{ }^{\circ} \mathrm{C}$ in the culture collection of microorganisms of the "Laboratorio di Ecologia dei Funghi Marini", DEB (University of Tuscia, Viterbo, Italy). The test strains (Aspergillus flavus IG133, Trichoderma pleuroticola IG137, Penicillium griseofulvum TSF04, Bacillus pumilus KB66 and Escherichia coli JM109) were from the same culture collection. Strains had been revitalized and sub-cultured on Malt Extract Agar Seawater (MEAs) medium (50 g MEA - Sigma - Aldrich dissolved in $1 \mathrm{~L}$ of filtered seawater) and Luria Bertani Seawater (LBs) broth (25 g LB - Sigma -Aldrich dissolved in $1 \mathrm{~L}$ of filtered seawater) for the fungal and bacterial strains, respectively.

\section{Phylogenetic analysis}

Strain IG100 was previously attributed by ITS and $\beta$-tubulin (tub2) gene analyses to the species Mariannaea humicola [30].

The phylogenetic analysis was carried out on $\beta$-tubulin (tub2) gene, partial cds utilizing the sequences present in the NCBI (National Center for Biotechnology Information advances science and health by providing access to biomedical and genomic information) for the Mariannaea species. A Bayesian Inference was performed [57]. For this analysis, the best fitting evolution model was obtained using the jModeltest software [58] under 88 possible substitution models. The model, obtained using the Akaike Information Criterion (AIC), was TIM1ef, $\mathrm{G}=0.430$ [59]. The Bayesian Posterior Probability analysis (BPP) was carried out using the Markov Chain Monte Carlo algorithm with generations number $=1,000,000$, sub-sampling frequency $=100$ and a burn-in fraction $=0.25$. BPP values are reported in the resulting tree.

\section{Preliminary screening}

The preliminary screening for antifungal and antibacterial activity was carried out with the agar plug diffusion method and agar well diffusion method, this last to evaluate the activity of the compounds in liquid condition [36]. All tests were carried out on saline media and test organisms were selected among marine and/or salt tolerant strains to avoid interferences related to salt presence.

The halotolerant strains of Bacillus pumilus KB66, Escherichia coli JM109 and Penicillium griseofulvum TSF04 were used as test organisms.

To produce standardized inoculum the bacteria were grown in LBs for $24 \mathrm{~h}$ at $30{ }^{\circ} \mathrm{C}$ in an orbital shaker at $150 \mathrm{rpm}$ and the fungus in MEAs for 7 days at $25^{\circ} \mathrm{C}$. Conidia suspensions were prepared in sterile filtered seawater supplemented with $0.01 \%$ of Tween 80 and diluted to obtain a final inoculum ranging from $0.5 \times 10^{5}$ to $1.0 \times 10^{5}$. Test plates used in the following tests were inoculated by spreading $100 \mu \mathrm{L}$ of bacteria culture and $300 \mu \mathrm{L}$ of spore suspension.

\section{Plug diffusion method}

Mariannaea humicola IG100 was cultured for 7 days on MEAs medium supplemented with $0.2 \mathrm{~g} / \mathrm{L}$ streptomycin sulfate at $25^{\circ} \mathrm{C}$; agar plots were aseptically cut near the front of the colony and deposited on the agar surface of plates previously inoculated by test organisms. After incubation $\left(24 \mathrm{~h}, 30{ }^{\circ} \mathrm{C}\right.$ for bacteria and $48-72 \mathrm{~h}$, $25^{\circ} \mathrm{C}$ for fungus) the antimicrobial activity was estimated measuring the inhibitions area (halos).

\section{Well diffusion method}

Strain IG100 was cultured in Malt Extract Seawater (MEs) [30]. Five Erlenmeyer flask (1000 mL), containing $250 \mathrm{~mL}$ of medium, were inoculated with $1 \mathrm{mg} / \mathrm{mL}$ dry weight of mycelium grown for 5 days on MEAs and incubated for 12 days at $25^{\circ} \mathrm{C}$ on a rotary shaker $(150 \mathrm{rpm})$. Subsequently, one Erlenmeyer flask culture was aseptically filtered to separate the broth from the biomass; the others cultures were directly extracted with EtOAc (1 L x 3 times). The EtOAc extract solution was concentrated to dryness by a rotary evaporator and utilized as crude extract. In each inoculated test plate, four holes $(6-8 \mathrm{~mm})$ were punched aseptically with a sterile cork 
borer. $100 \mu \mathrm{L}$ of broth or EtOAc extract at $0.6 \mathrm{mg} / \mathrm{mL}$, $2 \%$ DMSO, were added in two of the holes. While the remaining two holes were used for a positive (Streptomycin $0.2 \mathrm{mg} / \mathrm{mL}$ for bacteria and Myconazole $0.05 \mathrm{mg} / \mathrm{mL}$ for fungal strain) and negative control (culture media). Plates were incubated as reported above, the inhibition zone around the wells were measured and the antimicrobial activity was estimated as:

$$
\text { Antimicrobial activity }(\%)=(\mathrm{IC}-\mathrm{IS}) / \mathrm{IC} \times 100
$$

where, IC is the inhibition area in positive well and IS the inhibition area in well containing potential antimicrobial agent. Each analysis was carried out in triplicate.

\section{Antifungal activity assay}

The biological activities of EtOAc extract and its principal compounds were tested in a liquid growth medium (MBs) against $P$. griseofulvum utilizing the broth dilution methods. Compounds were first dissolved in DMSO, which was then diluted to a $2 \%$ aqueous solution to obtain each compound concentration of $5 \times 10^{-3} \mathrm{M}$. The compounds were added, in a 24-well microplate, to the suspension of the P. griseofulvum spore $\left(1 \times 10^{5} \mathrm{~m} / \mathrm{L}\right)$ to obtain final concentrations of $1,10,100,1000 \mu \mathrm{g} / \mathrm{mL}$. The conidial suspension was prepared in MEBs as reported above. DMSO at appropriate concentrations was used as control treatments.

MIC values were determined for the crude EtOAc extract and active fractions against the following fungal strains: A. flavus IG133, P. griseofulvum TSF04 and T. pleuroticola IG137. The broth micro-dilution methods in a 96-well microplate was utilized; twofold dilutions of the antifungal agents, Myconazole as positive control and a negative control with DMSO (concentrations $<2 \%$ ) were made. The test was carried out in duplicate utilizing two initial concentrations and the relative twofold dilutions: $\mathrm{S} 1,1000-1 \mu \mathrm{g} / \mathrm{mL}$ and $\mathrm{S} 2,100-0.1 \mu \mathrm{g} / \mathrm{mL}$. Spore suspensions of the test organisms were standardized to the final concentrations of $0.5 \times 10^{5}$ conidia $\mathrm{m} / \mathrm{L}$. The 96 -well microplates were incubated for $48 \mathrm{~h}$ at $25^{\circ} \mathrm{C}$.

For the determination of MIC endpoint, a viewing device (Canon visualizer RE450) was utilized.

Fungistatic or fungicidal activities were determined by subcultures in MEAs $20 \mu \mathrm{L}$ of the spore suspensions taken from the MIC wells.

\section{Isolation and characterization of bioactive secondary metabolites-chemistry general}

Reagents and solvents were obtained from commercial suppliers (Sigma-Aldrich Srl, Milan, Italy) and used without further purification. TLC chromatography was performed on precoated aluminium silica gel SIL
G/UV254 plates (Macherey-Nagel \& Co.). The detection occurred by UV lamp (254 nm). Merck silica gel 60 was used for flash chromatography (23-400 mesh). All products were dried in high-vacuum $\left(10-3\right.$ mbar). ${ }^{1} \mathrm{H}$ NMR and ${ }^{13} \mathrm{C}$ NMR spectra were measured on a Bruker Avance DRX400 (400 MHz/100 MHz) spectrometer using TMS as internal standard. Chemical shifts in ${ }^{1} \mathrm{H}$ NMR spectra are reported in parts per million (ppm) on the $\delta$ scale from an internal standard of residual $\mathrm{CDCl}_{3}$ (7.28 ppm). Data are reported as follows: chemical shift, multiplicity $(\mathrm{s}=$ singlet, $\mathrm{d}=$ doublet, $\mathrm{t}=$ triplet, $\mathrm{q}=$ quartet, $\mathrm{m}=$ multiplet, $\mathrm{br}=$ broad), coupling constant in hertz (Hz), and integration. Chemical shifts of ${ }^{13} \mathrm{C}$ NMR spectra are reported in ppm from the central peak of $\mathrm{CDCl}_{3}$ (77.23 ppm). HRESIMS spectra were recorded with a Thermo Scientific Q Exactive hybrid quadrupoleOrbitrap mass spectrometer. Infrared (IR) spectra were recorded on a Perkin-Elmer 2000 FT-IR. A semipreparative UHPLC Thermo Scientific Dionex Ultimate 3000 equipped with multi-wave length detector was used for purification. The column used was a Thermo Scientific Hypersil GOLD (15.0 cm length, $4.6 \mathrm{~mm}$ I.D., $3 \mu \mathrm{m}$ particle size) eluted with mixtures of water containing $0.05 \%$ formic acid ( $\mathrm{HCOOH}$; solvent $\mathrm{A}$ ) and acetonitrile (solvent B) at a flow rate of $0.5 \mathrm{~mL} / \mathrm{min}$. Detection was at $254 \mathrm{~nm}$ and runtime was set at $60 \mathrm{~min}$.

The ethyl acetate extract was concentrated in vacuo. The dry residue $(55 \mathrm{mg}$ ) was purified by repeated cycles of silica gel chromatography using dichloromethane/ methanol (98:2) as eluent. Five major fractions (PO1PO5) were isolated from the overall EtOAc extract (5.9, $10.5,9.5,14.6$, and $9.5 \mathrm{mg}$, respectively). Semipreparative UHPLC was performed to further purify the fractions endowed with the higher biological activity (PO3 and PO5) obtaining $9.1 \mathrm{mg}$ of compound $\mathbf{1}$ and $8.9 \mathrm{mg}$ of compound 2 .

Terpestacin 1: pale-yellow oil; $[\alpha]_{D}=-21$ (c 0.1 , $\mathrm{MeOH}$ ); IR (neat) 3365, 2932, 1699, 1653/cm; ${ }^{1} \mathrm{H}$ NMR $\left(400 \mathrm{MHz}, \mathrm{CDCl}_{3}\right) \delta 5.79(\mathrm{~s}, 1 \mathrm{H}), 5.41(\mathrm{~m}, 1 \mathrm{H}), 5.25(\mathrm{dd}$, $J=10.1,5.2 \mathrm{~Hz}, 1 \mathrm{H}), 5.14(\mathrm{~m}, 1 \mathrm{H}), 4.07$ (dd, $J=10.1$, $4.0 \mathrm{~Hz}, 1 \mathrm{H}), 3.90(\mathrm{dd}, J=10.4,7.0 \mathrm{~Hz}, 1 \mathrm{H}), 3.83(\mathrm{dd}$, $J=10.4,5.5 \mathrm{~Hz}, 1 \mathrm{H}), 2.72(\mathrm{dd}, J=11.3,2.1 \mathrm{~Hz}, 1 \mathrm{H})$, $2.68(\mathrm{~m}, 1 \mathrm{H}), 2.45(\mathrm{~d}, J=17.4 \mathrm{~Hz}, 1 \mathrm{H}), 2.40(\mathrm{dd}, J=13.7$, $10.4 \mathrm{~Hz}, 1 \mathrm{H}), 2.22-2.22(\mathrm{~m}, 2 \mathrm{H}), 2.12-2.12(\mathrm{~m}, 2 \mathrm{H})$, 2.04-1.90 (m, 2H), 1.80-1.68 (m, 3H), $1.65(\mathrm{~s}, 3 \mathrm{H}), 1.64$ $(\mathrm{s}, 3 \mathrm{H}), 1.58(\mathrm{~s}, 3 \mathrm{H}), 1.30(\mathrm{~d}, J=7.3 \mathrm{~Hz}, 3 \mathrm{H}), 1.01(\mathrm{~s}$, $3 \mathrm{H}) ;{ }^{13} \mathrm{C}$ NMR $\left(100 \mathrm{MHz}, \mathrm{CDCl}_{3}\right) \delta 208.0,149.0,146.8$, 138.3, 136.7, 133.1, 129.1, 124.5, 121.7, 76.7, 66.3, 49.8, 49.1, 40.5, 39.5, 37.3, 35.1, 30.0, 29.0, 24.0, 16.4, 15.8, 15.5, 14.6, 10.7. ppm; HRESIMS $m / z[\mathrm{M}+\mathrm{Na}]^{+}$calcd. for $\mathrm{C}_{25} \mathrm{H}_{38} \mathrm{O}_{4} \mathrm{Na}$ 425.2662, found 425.2682.

19-acetyl-4-hydroxydictyodiol 2: colorless oil; $[\alpha]_{\mathrm{D}}=$ - 43 (c 0.02, $\mathrm{CHCl}_{3}$ ); IR (neat) 3439, 2921, 1737, 1638, 
1455, $1381 \mathrm{~cm}^{-1}$; NMR ${ }^{1} \mathrm{H}\left(\mathrm{CDCl}_{3}, 400 \mathrm{MHz}\right) \delta 5.82$ (dd, $J=8.4,3.0 \mathrm{~Hz}, 1 \mathrm{H}), 5.30(\mathrm{~d}, J=11.4 \mathrm{~Hz}, 1 \mathrm{H}), 5.07(\mathrm{t}$, $J=6.6 \mathrm{~Hz}, 1 \mathrm{H}), 4.47(\mathrm{~d}, J=12.6 \mathrm{~Hz}, 1 \mathrm{H}), 4.39$ (d, $J=12.6$, $\mathrm{Hz}, 1 \mathrm{H}), 4.28(\mathrm{br}, 1 \mathrm{H}), 3.81(\mathrm{t}, J=10.2 \mathrm{~Hz}, 1 \mathrm{H}), 3.55(\mathrm{dd}$, $J=10.2,4.2 \mathrm{~Hz}, 1 \mathrm{H}), 3.14(\mathrm{dd}, J=9.6,4.2 \mathrm{~Hz}, 1 \mathrm{H}), 3.11$ (m, $1 \mathrm{H}), 2.63(\mathrm{dd}, J=14.4,9.0 \mathrm{~Hz}, 1 \mathrm{H}), 2.37(\mathrm{~d}, J=12.6$, $1 \mathrm{H}), 2.14(\mathrm{dd}, J=12.6,3.0 \mathrm{~Hz}, 1 \mathrm{H}), 2.09(\mathrm{br}, 1 \mathrm{H}), 2.06$ (s, 3H), $2.00(\mathrm{~m}, 1 \mathrm{H}), 1.97(\mathrm{~s}, 3 \mathrm{H}), 1.94(\mathrm{~m}, 1 \mathrm{H}), 1.83$ (m, $1 \mathrm{H}), 1.68(\mathrm{~s}, 3 \mathrm{H}), 1.60(\mathrm{~s}, 3 \mathrm{H}), 1.30(\mathrm{~m}, 1 \mathrm{H}), 1.21(\mathrm{~m}$, $1 \mathrm{H}), 1.02(\mathrm{~d}, J=6.6,3 \mathrm{H}) \mathrm{ppm} ;{ }^{13} \mathrm{C}\left(\mathrm{CDCl}_{3}, 100 \mathrm{MHz}\right) \delta$ $170.7,142.4,135.2,131.9,130.0,128.5,124.5,74.6,67.0$, $60.8,51.4,49.5,41.5,38.7,33.3,28.2,26.2,25.8,21.2$, 20.4, 17.9, 16.4 ppm; HRESIMS $m / z[\mathrm{M}+\mathrm{Na}]^{+}$calcd. for $\mathrm{C}_{22} \mathrm{H}_{36} \mathrm{O}_{4} \mathrm{Na}$, 387.2511, found 387.2508.

\section{Authors' contributions}

$M P, P B$ and $M F$ conceived and designed the experiments. $L B, R S, P B$ and $M P$ performed the experiments. $L B, R S, P B, M P$ and MF analyzed the data. MP and RS contributed reagents, materials and analysis tools. LB, RS, PB, MP and MF wrote the manuscript. LB, RS, PB, MP and MF planned the graphical features of the manuscript. $L B, R S, P B, M P$ and $M F$ revised the manuscript. All authors read and approved the final manuscript.

\section{Funding}

Not applicable.

\section{Availability of data and materials}

The authors promise the availability of supporting data.

\section{Ethics approval and consent to participate}

Not applicable.

\section{Consent for publication}

The authors provide consent for publication.

\section{Competing interests}

The authors declare that they have no competing interests.

\section{Author details}

1 Department of Ecological and Biological Sciences, University of Tuscia, Largo Università snc, 01100 Viterbo, Italy. ${ }^{2}$ Laboratory of Applied Marine Microbiology (Conisma), University of Tuscia, Largo Università snc, 01100 Viterbo, Italy. ${ }^{3}$ Laboratory of Ecology of Marine Fungi (Conisma), University of Tuscia, Largo Università snc, 01100 Viterbo, Italy.

Received: 4 August 2020 Accepted: 25 September 2020

Published online: 01 October 2020

\section{References}

1. Fenice M, Gallo AM, Juarez-Jimenez B, Gonzalez-Lopez J. Screening for extracellular enzyme activities by bacteria isolated from samples collected in the Tyrrhenian Sea. Ann Microbiol. 2007:57:93-9.

2. Trincone A. Marine biocatalysts: enzymatic features and applications. Mar Drugs. 2011;9:478-99.

3. Bonugli-Santos RC, Dos Santos Vasconcelos MR, Passarini MR, Vieira GA, Lopes VC, Mainardi PH, Feitosa VA. Marine-derived fungi: diversity of enzymes and biotechnological applications. Front Microbiol. 2015;6:1-15.

4. Bhadury P, Mohammad BT, Wright PC. The current status of natural products from marine fungi and their potential as anti-infective agents. $\mathrm{J}$ Ind Microbiol Biotechnol. 2006;33:325. https://doi.org/10.1007/s1029 5-005-0070-3.

5. Blunt J, Carroll A, Copp B, Davis R, Keyzers R, Prinsep M. Marine natural products. Nat Prod Rep. 2018:35:8-53.
6. Thompson CC, Kruger RH, Thompson FL. Unlocking marine biotechnology in the developing world. Trends Biotechnol. 2017; 35:1119-21. https //doi.org/10.1016/j.tibtech.2017.08.005.

7. Debashish G, Malay S, Barindra S, Joydeep M. Marine enzymes. In: Ulber R, Le Gal Y, editors. Marine biotechnology I. Advances in biochemical engineering/biotechnology. Berlin: Springer; 2005. p. 189-218.

8. Thirunavukkarasu N, Jahnes B, Broadstock A, Rajulu MG, Murali TS, Gopalan V, Suryanarayanan TS. Screening marine-derived endophytic fungi for xylan-degrading enzymes. Curr Sci. 2015:109:112-20.

9. Atalla MM, Zeinab HK, Eman RH, Amani AY, Abeer AAEA. Screening of some marine-derived fungal isolates for lignin degrading enzymes (LDEs) production. Agric Biol J N Am. 2010;1:591-9.

10. Cao J, Xiao-Ming L, Li XM, Li HL, Meng LH, Wang BG. New lactone and isocoumarin derivatives from the marine mangrove derived endophytic fungus Penicillium coffeae MA-314. Phytochem Lett. 2019; 32:1-5. https:// doi.org/10.1016/j.phytol.2019.04.018.

11. Corral P, Esposito FP, Tedesco P, Falco A, Tortorella E, Tartaglione, Festa C, D'Auria MV, Gnavi G, Varese GC, de Pascale D. Identification of a Sorbicillinoid-producing Aspergillus strain with antimicrobial activity against Staphylococcus aureus: a new polyextremophilic marine fungus from Barents Sea. Mar Biotechnol. 2018;20:502-11. https://doi.org/10.1007/ s10126-018-9821-9.

12. Liu Y, Mándi A, Li XM, Meng LH, Kurtán T, Wang BG. Peniciadametizine A. a dithiodiketopiperazine with a unique spiro [furan-2, $7^{\prime}$ - pyrazino $[1,2-b][1$, 2] oxazine] skeleton, and a related analogue, Peniciadametizine $B$, from the marine sponge-derived fungus Penicillium adametzioides. Mar Drugs. 2015; 13: 3640-52. https://doi.org/10.3390/md13063640.

13. Li X, Li XM, Xu GM, Li CS, Wang BG. Antioxidant metabolites from marine alga-derived fungus Aspergillus wentii EN-48. Phytochem Lett. 2014;7:120-23. https://doi.org/10.1016/j.phytol.2013.11.008.

14. Overy DP, Bayman P, Kerr RG, Bills GF. An assessment of natural product discovery from marine (sensu strictu) and marine-derived fungi. Mycology. 2014;5:145-67. https://doi.org/10.1080/21501203.2014.931308.

15. Tarman K, Palm GJ, Porzel A, Merzweiler K, Arnold N, Wessjohann LA, Unterseher $\mathrm{M}$, Lindequist $\mathrm{U}$. Helicascolide $\mathrm{C}$, a new lactone from an Indonesian marine algicolous strain of Daldinia eschscholzii (Xylariaceae, Ascomycota). Phytochem Lett. 2012; 5:83-8. https://doi.org/10.1016/J. PHYTOL.2011.10.006.

16. Wu Q, Zhang M, Wu K, Liu B, Cai J, Pan R. Purification and characteristics of fucoidanase obtained from Dendryphiella arenaria TM94. J Appl Phychol. 2011;23:197-203. https://doi.org/10.1007/s10811-010-9588-5.

17. Cueto M, Jensen PR, Kauffman C, Fenical W, Lobkovsky E, Clardy J. Pestalone, a new antibiotic produced by a marine fungus in response to bacterial challenge. J Nat Prod. 2001; 64: 1444-6. https://doi.org/10.1021/ np0102713.

18. Shin J, Fenical W. Isolation of gliovictin from the marine deuteromycete Asteromyces cruciatus. Phytochemistry. 1987;26:3347. https://doi. org/10.1016/S0031-9422(00)82503-0.

19. Giovannini V, Barghini P, Gorrasi S, Fenice M, Pasqualetti M. Marine fungi: a potential source of novel enzymes for environmental and biotechnological applications. J Environ Prot Ecol. 2019;20:1214-22.

20. Pasqualetti M, Barghini P, Giovannini V, Fenice M. High production of chitinolytic activity in halophilic conditions by a new marine strain of Clonostachys rosea. Molecules. 2019; 24:1880. https://doi.org/10.3390/ molecules24101880.

21. Ali I, Akbar A, Yanwisetpakdee B, Prasongsuk S, Lotrakul P, Punnapayak H. Purification, characterization, and potential of saline waste water remediation of a polyextremophilic a-amylase from an obligate halophilic Aspergillus gracilis. BioMed Res Int. 2014. https://doi.org/10.1155/2014/106937.

22. Corinaldesi C, Barone G, Marcellini F, Dell'Anno A, Danovaro R. Marine microbial-derived molecules and their potential use in cosmeceutical and cosmetic products. Mar Drugs. 2017;15:118. https://doi.org/10.3390/ md15040118.

23. Raghukumar S. Fungi in Coastal and Oceanic Marine Ecosystems. New York: Springer; 2017.

24. Yue Y, Yu H, Li R, Xing R, Liu S, Li P. Exploring the antibacterial and antifungal potential of jellyfish-associated marine fungi by cultivationdependent approaches. PLoS One. 2015. https://doi.org/10.1371/journ al.pone.0144394

25. Passarini MR, Rodrigues MV, da Silva M, Sette LD. Marine-derived filamentous fungi and their potential application for polycyclic aromatic 
hydrocarbon bioremediation. Mar Pollut Bull. 2011;62:364-70. https://doi. org/10.1016/j.marpolbul.2010.10.003.

26. Pasqualetti M, Mulas B, Canzonetti G, Benedetti A, Tempesta S. Effects of long-term heavy metal contamination on soil fungi in the Mediterranean area. 33. Mycol: Cryptogam; 2012. pp. 43-57.

27. Green EP, Short FT. World Atlas of Seagrasse. Berkeley: University of California Press; 2003

28. Hemminga M, Duarte CM. Seagrass ecology. Cambridge: Cambridge University Press; 2000

29. Panno L, Bruno M, Voyron S, Anastasi A, Gnavi G, Miserere L, Varese GC. Diversity, ecological role and potential biotechnological applications of marine fungi associated to the seagrass Posidonia oceanica. New Biotechnol. 2013; 30: 685-94. https://doi.org/10.1016/j.nbt.2013.01.010.

30. Pasqualetti M, Giovannini V, Barghini P, Gorrasi S, Fenice M. Diversity and ecology of culturable marine fungi associated with Posidonia oceanica leaves and their epiphytic algae Dictyota dichotoma and Sphaerococcus coronopifolius. Fungal Ecol. 2020. https://doi.org/10.1016/j.funec 0.2019 .100906$.

31. Gnavi G, Ercole E, Panno L, Vizzini A, Varese GC. Dothideomycetes and Leotiomycetes sterile mycelia isolated from the Italian seagrass Posidonia oceanica based on rDNA data. SpringerPlus. 2014;3:508. https://doi. org/10.1186/2193-1801-3-508.

32. Cuomo V, Vanzanella F, Fresi E, Cinelli F, Mazzella L. Fungal flora of Posidonia oceanica and its ecological significance. Trans Br Mycol Soc. 1985;84:35-40. https://doi.org/10.1016/S0007-1536(85)80217-5.

33. Lombard L, Van der Merwe NA, Groenewald JZ, Crous PW. Generic concepts in Nectriaceae. Stud Mycol. 2015:80:189-245.

34. Lukassen MB, Saei W, Sondergaard TE, Tamminen A, Kumar A, Kempken F, Wiebe MG, Sorensen JL. Identification of the scopularide biosynthetic gene cluster in Scopulariopsis brevicaulis. Mar Drugs. 2015;13:4331-43. https://doi.org/10.3390/md13074331.

35. Sepcic K, Zalar P, Gunde-Cimerman N. Low water activity induces the production of bioactive metabolites in halophilic and halotolerant fungi. Mar Drugs. 2011;9:43-58. https://doi.org/10.3390/md9010043.

36. Balouiri M, Sadiki M, Ibnsouda SK. Methods for in vitro evaluating antimicrobial activity: a review. J Pharm Analy. 2016;6:71-9.

37. Banani H, Marcet-Houben M, Ballester AR, Abbruscato P, GonzálezCandelas L, Gabaldón T, Spadaro D. Genome sequencing and secondary metabolism of the postharvest pathogen Penicillium griseofulvum. BMC Genom. 2016;17:19. https://doi.org/10.1186/s12864-015-2347-x.

38. Chan J, Jamison TF. Synthesis of (-)-terpestacin via catalytic, stereoselective fragment coupling: siccanol Is terpestacin, Not 11 -terpestacin. J Am Chem Soc. 2003;125:11514-5.

39. Oka M, limura S, Tenmyo O, Sawada Y, Sugawara M, Ohkusa N, Yamamoto H, Kawano K, Hu SL, Fukagawa Y, Oki T. Terpestacin, a new syncytium formation inhibitor from Arthrinium sp. J Antibiot (Tokyo). 1993;46:367-73.

40. Narita K, Minami A, Ozaki T, Liu C, Kodama M, Oikawa H. Total biosynthesis of antiangiogenic agent (-)-terpestacin by artificial reconstitution of the biosynthetic machinery in Aspergillus oryzae. J Org Chem. 2018;83:7042-8.

41. Ye B, Ding W, Wang PM, Xu J. Two new sesterterpenes from marinederived fungus Arthrinium sp. Chem Nat Compd. 2019;55:281-4.

42. Liu D, Li XM, Li CS, Wang BG. Sesterterpenes and 2H-Pyran-2-ones (=aPyrones) from the mangrove-derived endophytic fungus Fusarium proliferatum MA-84. Helv Chim Acta. 2013;96:437-44. https://doi.org/10.1002/ hlca.201200195.

43. Masi M, Aloi F, Nocera P, Cacciola SO, Surico G, Evidente A. Phytotoxic Metabolites Isolated from Neufusicoccum batangarum, the causal agent of the scabby canker of cactus pear (Opuntia ficus-indica L.). Toxins. 2020;12:126. https://doi.org/10.3390/toxins12020126.
44. Park KC, Choi SH. Effects of endostatin and a new drug terpestacin against human neuroblastoma xenograft and cell lines. Pediatr Surg Int. 2013:29:1327-40

45. Jung HJ, Shim JS, Lee J, Song YM, Park KC, Choi SH, Kim ND, Yoon JH, Mungai PT, Shumacker PT, Kwon HJ. Terpestacin inhibits tumor angiogenesis by targeting UQCRB of mitochondrial complex III and suppressing hypoxia-induced reactive oxygen species production and cellular oxygen sensing. J Biol Chem. 2010;285:11584-95.

46. Logrieco A, Moretti A, Fornelli F, Fogliano V, Ritieni A, Caiaffa MF, Randazzo G, Bottalico A, Macchia L. Fusaproliferin production by Fusarium subglutinans and its toxicity to Artemia salina, SF-9 insect cells, and IARC/LCL 171 human B lymphocytes. Appl Environ Microbiol. 1996;62:3378-84.

47. Phan CS, Li H, Kessler S, Solomon PS, Piggott AM, Chooi YH. Bipolenins $\mathrm{K}-\mathrm{N}$ : New sesquiterpenoids from the fungal plant pathogen Bipolaris sorokiniana. Beilstein J Org Chem. 2019;15:2020-8.

48. Masi M, Meyer S, Górecki M, Pescitelli G, Clement S, Cimmino A, Evidente A. Phytotoxic activity of metabolites isolated from Rutstroemia sp. n., the causal agent of bleach blonde syndrome on cheatgrass (Bromus tectorum). Molecules. 2018;23:1734. https://doi.org/10.3390/molecules230717 34.

49. Cimmino A, Sarrocco S, Masi M, Diquattro S, Evidente M, Vannacci G, Evidente A. Fusaproliferin, terpestacin and their derivatives display variable allelopathic activity against some ascomycetous fungi. Chem Biodivers. 2016;13:1593-600.

50. Cheng S, Zhao M, Sun Z, Yuan W, Zhang S, Zheng Z, Yuepiao C, Jianyong $D$, Kexin $H$, Pengcheng $Y$. Diterpenes from a chinese collection of the brown alga Dictyota plectens. J Nat Prod. 2014;77:2685-93.

51. Chen J, Li H, Zhao Z, Xia X, Li B, Zhang J, Yan X. Diterpenes from the marine algae of the genus Dictyota. Mar Drugs. 2018;16:159. https://doi. org/10.3390/md16050159.

52. Xia X, Li B, Hou Y, Zhang J, Yan X. Diterpenes from the marine brown algae of the genus Dilophus. Nat Prod Commun. 2020. https://doi.org/10.3390/ md16050159.

53. Betschart L, Altmann KH. Xenicane Natural Products: Biological Activity and Total Synthesis. Curr Pharm Des. 2015;21:5467-88.

54. de Hoog GS, Guarro J, Gené J, Figueras MJ. Atlas of clinical fungi, second edition. Utrecht: Centraalbureau voor Schimmelcultures; 2000.

55. Geiser DM, Dorner JW, Horn BW, Taylor JW. The phylogenetics of mycotoxin and sclerotium production in Aspergillus flavus and Aspergillus oryzae. Fungal Genet Biol. 2000;31:169-79. https://doi.org/10.1006/ fgbi.2000.1215.

56. Błaszczyk L, Siwulski M, Sobieralski K, Frużyńska-Jóźwiak D. Diversity of Trichoderma spp. causing Pleurotus green mould diseases in Central Europe. Folia Microbiol. 2013;2013(58):325-33.

57. Ronquist F, Huelsenbeck JP. MrBayes 3: Bayesian phylogenetic inference under mixed models. Bioinformatics. 2003;19:1572-4. https://doi. org/10.1093/bioinformatics/btg180.

58. Posada D. jModelTest: phylogenetic model averaging. Mol Biol Evol. 2008;2008(25):1253-6.

59. Posada D, Buckley TR. Model selection and model averaging in phylogenetics: advantages of the AIC and Bayesian approaches over likelihood ratio tests. Syst Biol. 2004;2004(53):793-808. https://doi. org/10.1080/10635150490522304.

\section{Publisher's Note}

Springer Nature remains neutral with regard to jurisdictional claims in published maps and institutional affiliations. 